\title{
THE RELATIONSHIP OF BIOMASS TO PHOSPHATE UPTAKE BY ACINETOBACTER JUNII IN ACTIVATED SLUDGE MIXED LIQUOR
}

\author{
M. N. B. MOMBA and T. E. CLOETE
}

\section{INTRODUCTION}

Phosphate is recognized as one of the major nutrients contributing to the eutrophication of aquatic environments. Because of this, removal of phosphate from wastewater has received much attention in recent years (Barnard, 1976; Buchan, 1983; Toerien et al., 1990). The prevention of eutrophication can be achieved by removing phosphate from wastewater by chemical (Arvin and Bundgaard, 1982; Toerien et al., 1990) as well as by biological (Buchan, 1980; Gleisberg, 1992) or by combination of both (Arvin and Bundgaard, 1982) methods.

Chemical removal used in most countries is expensive. It involves the addition of lime, aluminium and ferric chloride, and goes along with the cost of the mentioned chemicals and accumulation of large quantities of chemical waste sludge. This disadvantage has led to intensified investigations into biological phosphate removal, which may provide a more cost effective alternative to chemical treatment methods (Fuhs and Chen, 1975; Grady and Lim, 1980).

Bio-phosphate removal is characterized by phosphate removal in excess of metabolic requirements (Comeau et al., 1986). The phenomenon of enhanced phosphate removal by activated sludge systems, although well documented (Srinath et al., 1959; Nicholls and Osborn, 1979; Toerien et al., 1990), is not yet clearly defined or fully understood.

Excess phosphate uptake by bacteria in the activated sludge process was observed for the first time by Vaker et al. (1967). Identification of the dominant bacteria responsible for phosphate removal has been elucidated (Buchan, 1983; Lotter and Murphy, 1985). Previous workers (Buchan, 1981; Lotter, 1985) have shown that Acinetobacter played an important role in phosphate removal by activated sludge systems. Experimental evidence has favored the biological uptake of phosphate, implicating Acinetobacter spp. as the responsible organism (Buchan, 1980, 1985). Acinetobacter spp. had, moreover, been isolated from the sludge by other workers who stressed the importance of Acinetobacter spp. in biological phosphate removal (Nicholls and Osborn, 1979). Strains of the genus Acinetobacter have frequently been isolated from activated sludge (Deinema et al., 1980; Lawson and Tonhazy, 1980).

Although Acinetobacter strains are the most intensively studied and best known polyphosphate bacteria in activated sludge, research in recent years indicated that Acinetobacter was not the dominant bacteria in activated sludge (Streichan et al., 1990; Auling et al., 1991). Some studies with municipal sludge showing enhanced biological phosphate removal indicated that Acinetobacter spp. accounted for 1 to $10 \%$ of the bacterial communities in laboratory and pilot scale activated sludge units (Brodisch and Joyner, 1983; Hiraishi et al., 1989). Cloete and Steyn (1988a), using a fluorescent antibody technique, showed that Acinetobacter could not account for all the biological phosphate removal in activated sludge. This implies that organisms other than Acinetobacter must coexist in order for enhanced phosphate removal to take place in activated sludge.

Moreover, the total phosphate content of bacteria is of practical importance for the activated sludge process. The phosphate content of Acinetobaceter cells are reported to vary from 2 to $10 \%$ depending on temperature, $\mathrm{pH}$, growth rate and substrate limitations (Deinema et al., 1985; Pauli, 1994). The average length of Acinetobacter cells ranged from 1.5 to $2.5 \mu \mathrm{m}$ (Junii, 1954) or from 1.0 to $1.5 \mu \mathrm{m}$ (Bosch, 1992). The polyphosphate containing cells have a cell volume ranging from 0.50 to $0.59 \mathrm{~mm}^{3}$ or less (Cloete and Steyn, 1988b) or 0.1 to $1.9 \mu^{3}$ (Bosch, 1992). This indicates that Acinetobacter cells are relatively small and could remove a maximum of $10^{-10}$ mg-cell $^{-1}$ phosphate. Using Acinetobacter number, volumes of phosphate granules, densities and phosphate contents, Cloete and Steyn (1988b) found that a maximum of $34 \%$ of the phosphate in activated sludge could be removed by Acinetobacter. Moreover, Bosch (1992) reported that concurrent growth and phosphate studies showed the removal of phosphate during the lag growth phase as well as stationary growth phase. In addition, the author stipulated that under conditions of increased nutrient availability, phosphate removal increased, possibly due to the resultant increase in biomass and not due to an enhanced phosphate accumulating ability of individual cells. This suggested that biomass could be a more important factor than type of organism with reference to biological phosphorus removal.

It is known that Acinetobacter junii is capable of enhanced phosphorus uptake. Therefore we used this 
organism to determine the relationship between growth rate and biomass and the phenomenon of phosphate removal in order to try and explain why activated sludge systems remove phosphate.

The aims of this study were consequently to investigate the relationship between biomass and phosphate uptake, as well as the relationship between growth and phosphate uptake of Acinetobacter junii in activated sludge mixed liquor.

\section{MATERIALS AND METHODS}

\section{Test organism}

A phosphorus accumulating Acinetobacter junii (strain AS33) was obtained from the Type Culture Collection in the Department of Microbiology and Plant Pathology, University of Pretoria, and maintained on Nutrient Agar (Biolab.). Plates were incubated at $28^{\circ} \mathrm{C}$ for $48 \mathrm{~h}$ before inoculation into the enrichment medium (Nutrient Broth).

\section{Culture medium used for phosphate uptake}

Mixed liquor samples drawn from the anaerobic and aerobic zones of a five stage Bardenpho activated sludge plant at Daspoort sewage works in Pretoria were settled in the laboratory for $2 \mathrm{~h}$. The supernatant from the mixed liquor was prefiltered three times through Whatman $\mathrm{N}^{\circ} \mathrm{l}$ filter paper and swirled on a vortex mixer for $2 \mathrm{~min}$. Samples from the anaerobic zone were diluted in tap water in order to obtain a phosphate concentration between ca $23 \mathrm{mg}^{-1} \mathrm{f}^{-1}$ and $c a 37 \mathrm{mg} . \mathrm{l}^{-1}$. The homogenised mixed liquor was prepared according to a modified version of the acetate enrichment medium of Fuhs and Chen (1975) as follows: 5 g..$^{-1}$ sodium acetate (BDH); 0.5 g. $1^{-1} \mathrm{Mg} \mathrm{SO}{ }_{4} 7 \mathrm{H}_{2} 0$ (Merck) and

0.18 g. $^{-1} \mathrm{KNO}_{3}$ (Merck) were added and the $\mathrm{pH}$ adjusted to $\mathrm{pH} 7$ with $2 \mathrm{~N} \mathrm{HC1}$ before autoclaving $\left(121^{\circ} \mathrm{C}, 15 \mathrm{~min}\right)$. This mixed liquor medium was used in all experiments.

\section{Biomass experiments}

Two methods were used for obtaining different initial biomass concentrations:

(a) Method I. Six loops of Acinetobacter junii cells were grown in $100 \mathrm{ml}$ sterile Nutrient Broth (Biolab.) under constant aeration on a rotary shake incubator $\left(80 \mathrm{rpm}\right.$.) at $28^{\circ} \mathrm{C}$ for $48 \mathrm{~h}$. Serial dilutions were made in $9 \mathrm{ml}$ sterile Ringers solution within the range of $10^{-2}$ to $10^{-5}$. Two flasks containing $250 \mathrm{ml}$ of sterile mixed liquor were inoculated with $1 \mathrm{ml}$ of the rest of bacterial culture (1st density); the second and third series, also containing $250 \mathrm{ml}$ of sterile mixed liquor were inoculated with the $10^{-3}$ (2nd density) and $10^{-5}$ (3rd density) dilutions, respectively. $1 \mathrm{ml}$ of each density was removed and plating of $10^{-6}$ to $10^{-8}$ dilutions were carried out on Nutrient Agar (Biolab) and colonies were counted after incubation at $28^{\circ} \mathrm{C}$ for $48 \mathrm{~h}$ in order to determine the initial biomass concentration. Flasks were incubated in a rotary shake incubator $\left(80 \mathrm{rpm}\right.$.) at $28^{\circ} \mathrm{C}$. Every hour, a $1 \mathrm{ml}$ sample was taken from the flasks for viable count determinations.

(b) Method II. In order to obtain high initial biomass concentrations, six loops of Acinetobacter junii cells were separately cultured in two series of flasks containing $100 \mathrm{ml}$ Nutrient Broth for $48 \mathrm{~h}$ on a rotary shake incubator at $28^{\circ} \mathrm{C}$. Cells from the enrichment medium were centrifuged for $20 \mathrm{~min}$ at 8000 $\mathrm{rpm}$. and washed three times with sterile distilled water. Harvested cells were then suspended in $250 \mathrm{ml}$ of mixed liquor medium. This was done as follows: cells from each of the first centrifuge tubes were suspended in $250 \mathrm{ml}$ of mixed liquor in $500 \mathrm{ml}$ Erlenmeyer flasks (1st density); cells from the second centrifuge tube were diluted in $9 \mathrm{ml}$ of sterile mixed liquor, $1 \mathrm{ml}$ of this was taken out and inoculated into the second Erlenmeyer (2nd density); $1 \mathrm{ml}$ from the second centrifuge tube was again removed and diluted in $9 \mathrm{ml}$ of mixed liquor and $1 \mathrm{ml}$ from this dilution was suspended in the third flask (3rd density). $1 \mathrm{ml}$ of each density was removed and diluted in $9 \mathrm{ml}$ of sterile Ringers solution within the range of $10^{-2}$ to $10^{-8}$ in order to determine the initial biomass concentration. All flasks were incubated in a rotary shake incubator $\left(80 \mathrm{rpm}\right.$.) at $28^{\circ} \mathrm{C}$. Viable count determinations were made hourly by the spread-plate technique, after samples were serially diluted in $9 \mathrm{ml}$ of sterile Ringers solution. All experiments were conducted in duplicate.

\section{Calculation of growth rates}

The specific growth rates ( $\mu$ expressed by time ${ }^{-1}$ ) were calculated by using the following mathematical expression: $\mu=\left(\operatorname{In} X-\operatorname{In} X_{0}\right)\left(t-t_{0}\right)^{-1}$ where the values, $X$ and $X_{0}$ corresponded to the concentrations of microorganisms (mass.volume ${ }^{-1}$ ) of culture at times $t$ and $t_{0}$ respectively (Stanier et al., 1976). Therefore, the generation time ( $g$, expressed in hours), also called doubling time and defined as the time required for the bacterial culture to increase by a factor of 2 , was derived by the above equation:

$\mu=\operatorname{In} 2 . g^{-1}$ or $g=$ In 2. $\mu^{-1}$ (Stanier et al., 1976). 


\section{Phosphate analysis}

Every hour, the phosphate content of the mixed liquor medium was analyzed by removing $1 \mathrm{ml}$ samples from the flasks with a syringe and filtering the samples through a $0.22 \mu \mathrm{m}$ filter (millipore) to remove all cells. Flasks containing $250 \mathrm{ml}$ of sterile mixed liquor treated in the same manner as inoculated mixed liquor medium were used as control. The filtered medium was used for phosphate determination using the P(VM) 14842 test kit (Merck) and the Merck SQ 118 photometer.

Table 1. Growth and phosphate uptake by using Achinetobacter jumii cell concentrations $\left(10^{4}, 10^{5}, 10^{6} \mathrm{cells}^{\mathrm{m}} \mathrm{m}^{-1}\right)$ as inoculum

\begin{tabular}{lccccccc}
\hline \multicolumn{3}{c}{ CFU. ml } \\
Time (h) & Before inc & After inc & $\mu \mathrm{h}^{-1}$ & $g$ & PR & PU* & PU** $^{*}$ \\
\hline \multirow{2}{*}{8} & $4.20 \times 10^{4}$ & $4.43 \times 10^{7}$ & 0.87 & 0.80 & 49.00 & 9 & - \\
& $1.42 \times 10^{5}$ & $8.20 \times 10^{7}$ & 0.80 & 0.87 & 82.25 & - & - \\
& $4.56 \times 10^{6}$ & $7.20 \times 10^{8}$ & 0.63 & 1.10 & 37.00 & 14.25 & 12.25 \\
& & & & & & & \\
& $4.20 \times 10^{4}$ & $7.75 \times 10^{8}$ & 0.41 & 1.69 & 49.00 & 17.50 & 3.50 \\
& $1.42 \times 10^{5}$ & $1.26 \times 10^{9}$ & 0.38 & 1.82 & 82.25 & 65.75 & 18.50 \\
& $4.56 \times 10^{6}$ & $1.47 \times 10^{10}$ & 0.34 & 2.04 & 37.00 & 28.25 & 26.25 \\
\hline
\end{tabular}

PR: maximum phosphate concentration after release.

PU*: phosphate uptake $=[\mathrm{PR}-$ phosphate after $8 \mathrm{~h}$ or after $24 \mathrm{~h}]$

PU**: phosphate uptake $=\left[\right.$ initial phosphate $35 \mathrm{mg} \cdot \mathrm{l}^{-1}-$ phosphate after $8 \mathrm{~h}$ or after $\left.24 \mathrm{~h}\right]$

$\mu . h^{-1}$ : growth rate

$g$ : generation time

\section{RESULTS AND DISCUSSION}

The patterns of phosphate removal by different cell concentrations of Acinetobacter junii are summarized in Tables 1-2 and Figs 1-6. Acinetobacter junii had the ability to remove phosphate in a mixed liquor medium containing 5 g. $1^{-1}$ sodium acetate. This ability was influenced by the initial biomass concentration. Results showed a close relationship between the concentration of phosphate uptake and the initial cell density (Figs 1-6).

In almost all experiments, a logarithmic increase in $A$. junii numbers occurred during the first $8 \mathrm{~h}$ after which the stationary growth phase was reached. During logarithmic growth, the F:M (Food: Mass) ratio was favourable for rapid growth of the bacteria. Consequently, the generation times were very short during the first $8 \mathrm{~h}$. The situation was reversed when cells reached the stationary growth phase (Table 1). This is due to the fact that cells had exhausted the substrates (5 g.l ${ }^{-1}$ sodium acetate and nutrient broth) necessary for growth and the growth of new cells was offset by the death of old cells. Basically, a high growth rate of $0.87 \mathrm{~h}^{-1}$ was related to a low initial biomass of $4.20 \times 10^{4}$ (Table 1 ) and a low growth rate was observed when $10^{8} \mathrm{cells}_{\mathrm{ml}}{ }^{-1}$ was used as initial biomass (Fig. 6).

Results illustrated in Figs 1-3 indicated the phenomenon of phosphate release during active growth over an $8 \mathrm{~h}$ period, although some phosphate $\left(14.25 \mathrm{mgl}^{-1}\right)$ was removed during this growth phase in the sample containing $10^{6}$ cells. $\mathrm{ml}^{-1}$ (Fig. 3). Uptake of phosphate only took place after the maximum growth rate of cells had occurred and when the stationary growth phase was reached. The removal of phosphate during the stationary growth phase was associated with the increase in A. junii biomass concentrations (over a 24h period) and with the nutrient deficiency. These results were not only in agreement with Harold (1963) who reported the accumulation of phosphate when growth ceased as the result of nutritional deficiency, but also support other workers who related this uptake of phosphate to an increase of the biomass concentration (Streichan et al., 1990; Bosch, 1992). It has been demonstrated that the accumulation of phosphate is reversed if growth is allowed to resume. The inverse relationship between phosphate release and growth can be linked to the competition between nucleic acid synthesis and polyphosphate for intracellular phosphate. Polyphosphate degradation is enhanced under conditions which permit rapid nucleic acid synthesis, the phosphate released being trapped in RNA. The high demand for phosphate therefore increased the rate of polyphosphate degradation (Harold, 1963).

A possible explanation for phosphate release during the growth process is the lack of energy required for maintaining the intracellular level of phosphate during growth. In numerous microorganisms, it has been confirmed that phosphate is 
Table 2. Growth and phosphate uptake by using $10^{6}, 10^{7}, 10^{8}$ A. junii cell concentrations as inoculum

\begin{tabular}{lccccccc}
\hline \multicolumn{2}{c}{ CFU. $l^{-1}$} & & \multicolumn{3}{c}{ Phosphate } \\
Time (h) & Before inc & After inc & $\mu . \mathrm{h}^{-1}$ & $g$ & PR & PU* $^{*}$ & PU** $^{* *}$ \\
\hline \multirow{2}{*}{12} & $1.43 \times 10^{6}$ & $1.07 \times 10^{9}$ & 0.55 & 1.26 & 35.00 & 22.00 & 10.00 \\
11 & $1.43 \times 10^{7}$ & $1.61 \times 10^{9}$ & 0.43 & 1.61 & 42.50 & 42.50 & 23.00 \\
8 & $1.28 \times 10^{8}$ & $1.03 \times 10^{9}$ & 0.26 & 2.67 & - & - & 13.50 \\
24 & $1.43 \times 10^{6}$ & $1.05 \times 10^{9}$ & 0.28 & 2.48 & 35.00 & 23.50 & 11.50 \\
& $1.43 \times 10^{7}$ & $1.05 \times 10^{9}$ & 0.18 & 3.85 & 42.50 & 37.00 & 17.50 \\
15 & $1.28 \times 10^{8}$ & $1.30 \times 10^{9}$ & 0.15 & 4.72 & - & - & 23.00 \\
\hline
\end{tabular}

PR: maximum phosphate concentration after release.

PU*; phosphate uptake $=$ [PR - phosphate after $8 \mathrm{~h}$ or after $24 \mathrm{~h}]$.

PU**: phosphate uptake $=$ [initial phosphate $35 \mathrm{mg}^{*-1}-$ phosphate after $8 \mathrm{~h}$ or after $\left.24 \mathrm{~h}\right]$.

$\mu . \mathrm{h}^{-1}$ : growth rate.

$g$ : generation time.

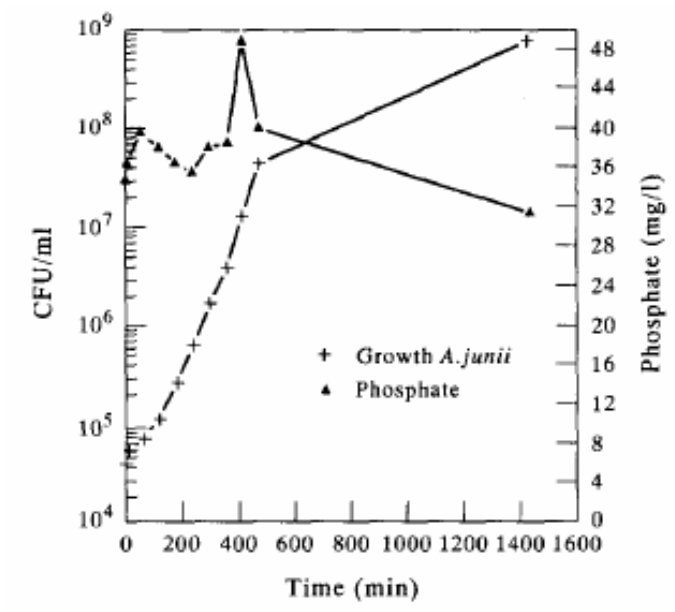

Fig. 1. Phosphate removal using $4.20 \times 10^{4}$ cells $\cdot \mathrm{ml}^{-1}$ initial cell density of $A$. jumii in activated sludge mixed liquor.

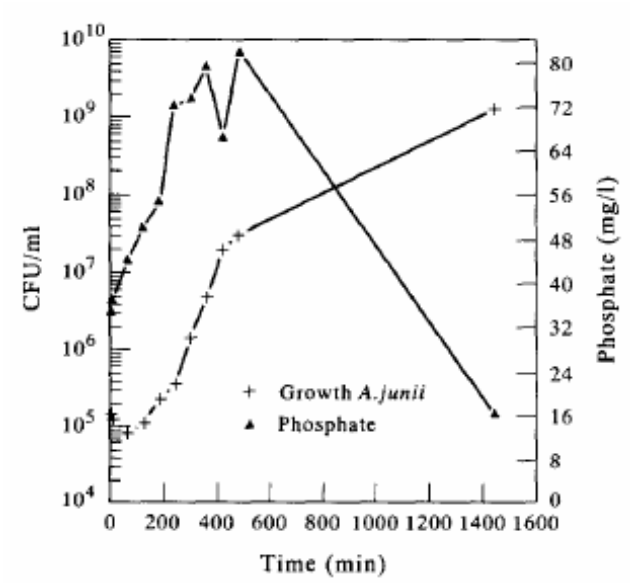

Fig. 2. Phosphate removal using $1.42 \times 10^{5}$ cells-mi ${ }^{-1}$ initial cell density of $A$. junit in activated sludge mixed liquor.

accumulated within the cells against a very high concentration gradient (Rosenberg et al., 1969). It can be speculated that the energy source required for maintaining the high intracellular level of phosphate against the concentration gradient is absent. This can be justified by a high concentration of phosphate within the cells. At any time, the polyphosphate content must reflect the balance between the rates of synthesis and degradation. If the phosphate concentration within the cells is larger than that of the surrounding liquids, polyphosphate rapidly degrades and the phosphate is quantitatively transferred to the nucleic acid fraction (Nicholls and Osborn, 1979). Since polyphosphate can function as a means of regulating the intracellular phosphate concentration, it may be hydrolyzed when the intracellular level of phosphate declines (Kulaev and Vagabov, 1983).

As previously noted, 5 g. . $^{-1}$ sodium acetate was added in the medium. The addition of acetate to the medium is often the reason for phosphate release. Electron microscopy showed the disappearance of intracellular polyphosphate granules during the acetate treatment, and release of phosphate into the external medium was therefore based on the presence of acetate (Murphy and Lotter, 1986). Lotter's observations (1985) indicated that the addition of acetate causes the extracellular orthophosphate level to rise to $55 \mathrm{mg}^{-\mathrm{l}^{-1}}$. This observation was also made in this study. In the sample containing $35 \mathrm{mg}^{-1} \mathrm{l}^{-1}$ initial phosphate concentration, the extracellular phosphate concentration increased to 82.25 mg..$^{-1}$ (Fig. 2). Phosphate release by addition of acetate was also observed by other workers (Barnard, 1976; Comeau et al., 1986).

A higher phosphate release of 82.25 mg. $^{-1}$ (Fig. 2) can also be associated with the presence of Nutrient Broth in the transfer bacterial suspension, which consists of meat extract, yeast extract, peptone and sodium chloride. Our results support the findings of Deinema et al. (1985) who stated that the higher phosphate release rates of sludge may be due to the activated sludge mixed liquor containing carbon compounds other than acetate, which is frequently used in pure culture. Moreover, these compounds must be present in the correct ratio. If not, they cannot result in 


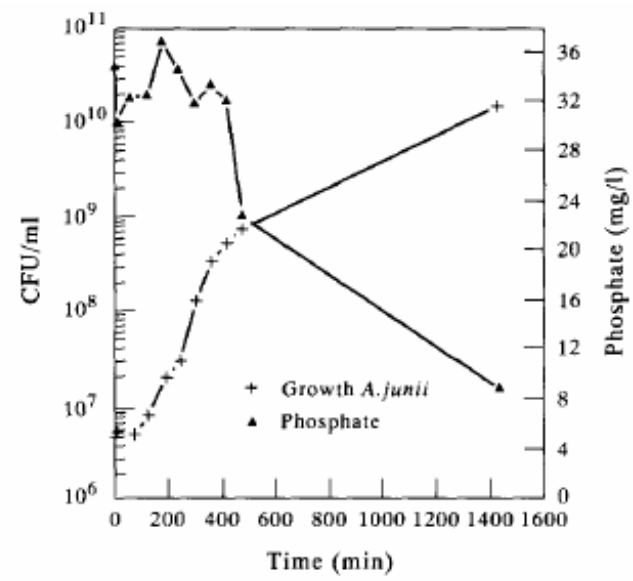

Fig. 3. Phosphate removal using $4.20 \times 10^{6}$ cells $\cdot \mathrm{ml}^{-1}$ initial cell density of $A$. junit in activated sludge mixed liquor.

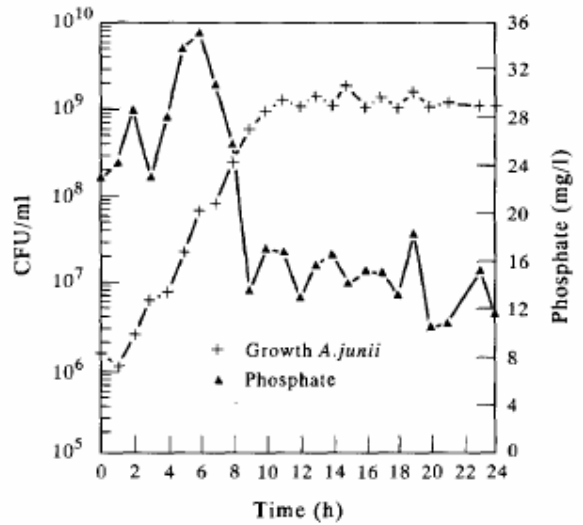

Fig. 4. Growth of $1.43 \times 10^{6}$ cells $\cdot \mathrm{ml}^{-1}$ initial cell density and phosphate removal of $A$. junii in activated sludge mixed liquor medium.

The experiments described above have not only indicated the release of phosphate but also the removal of phosphate. Little (Fig. 3) or no phosphate (Figs 1, 2) was removed during the lag growth phase. Some phosphate was on one occasion removed during the logarithmic growth phase (Fig. 3). The maximum phosphate concentration was removed when cells reached the stationary growth phase (Figs 1, 2, 3). This period corresponds to the cessation of nucleic acid synthesis and the exhaustion of an essential element other than phosphate in mixed liquor medium (Harold, 1963), a phenomena also observed in full scale plants. Enhanced uptake, then, refers to phosphate uptake by growing bacteria in excess to their normal metabolic needs. These results were similar to the results for an Aerobacter aerogenes culture in which a reciprocal relationship between polyphosphate accumulation and nucleic acid synthesis was determined (Harold, 1963).

During this study the excess phosphate uptake was, in some cases, associated with the degree of release as indicated in Table 1 and Fig. 2. In the sample containing $1.42 \times 10^{5}$ cells.ml $^{-1}$ (initial concentration) and $1.26 \times 10^{9}$ cells. $\mathrm{ml}^{-1}$ after incubation a release of $82.25 \mathrm{mgl}^{-1} \mathrm{P}$ was noted during growth and a removal of $65.75 \mathrm{mgl}^{-1} \mathrm{P}$ over a 24h period. This result confirms the findings of Tarn et al. (1992) who stated that phosphate release is related to phosphate uptake. The result also confirms the observations of Comeau et al. (1986) and observations made on full scale plants. Although the largest concentration of phosphate removal (65.75 mg. $\mathrm{l}^{-1}$ ) was influenced by the degree of phosphate release $\left(82.25 \mathrm{mg} .1^{-1}\right)$, uptake of phosphate was also associated with the final biomass in the culture medium (Table 1, Figs 1, 2, 3).

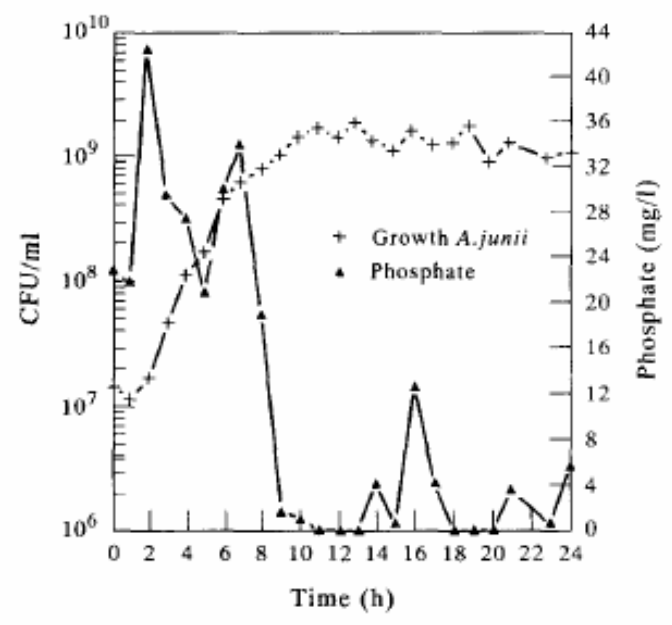

Fig. 5. Growth of $1.43 \times 10^{7}$ cells $\mathrm{ml}^{-1}$ initial cell density and phosphate removal of $A$. junii in activated sludge mixed liquor medium.

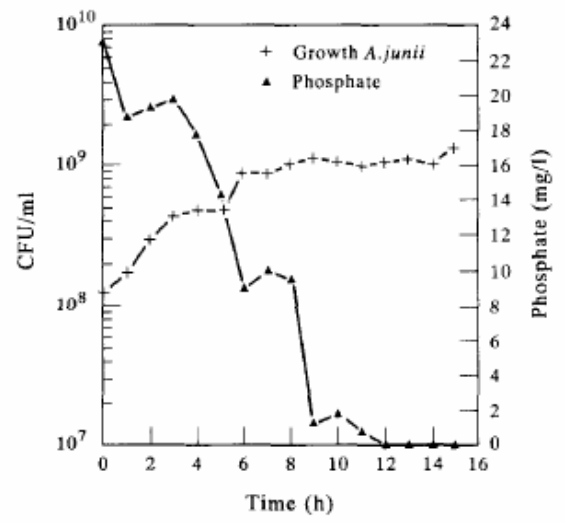

Fig. 6. Growth of $1.28 \times 10^{\star}$ cells $\cdot \mathrm{ml}^{-1}$ initial cell density and phosphate removal of $\boldsymbol{A}$. junii in activated sludge mixed liquor medium. 
Regarding the results in Table 2, all initial cell densities $\left(1.43 \times 10^{6}, 1.43 \times 10^{7}\right.$ and $1.28 \times 10^{8}$ cells.ml $\left.^{-1}\right)$ exhibited approximately a similar biomass $\left(10^{9}\right.$ cells. $\mathrm{ml}^{-1}$ ) over 12,11 and 8 h respectively (Figs $\left.4,5,6\right)$ during the logarithmic growth phase, after which the stationary growth phase was reached. However, the growth rates recorded during the logarithmic growth phase decreased, respectively, from $0.55,0.43$ and $0.26 \mathrm{~h}^{-1}$ (generation times 1.26 , 1.61 and $2.67 \mathrm{~h}$ ) to $0.28,0.18$ and $0.15 \mathrm{~h}^{-1}$ (generation times 2.48, 3.85 and $4.72 \mathrm{~h}$ ) during the stationary growth phase because of nutrient limitations. This is in agreement with observations in full scale plants, where carbon limitation has been indicated as a prerequisite for phosphate removal (Lötter, 1985).

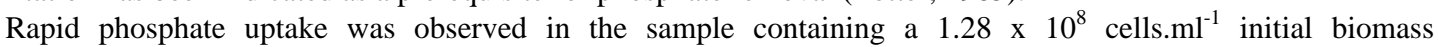
concentration (Fig. 6). Phosphate removal increased progressively with time, while cells grew very slowly. Excess removal of phosphate occurred over a period of $12 \mathrm{~h}$ (at the beginning of the stationary growth phase) with the absence of traces of residual phosphate in the medium. No trace of phosphate was noted when cells reached the stationary growth phase (Fig. 6). The slow growth and rapid phosphate removal confirms that slow growing cells often contains polyphosphate granules as reported by Harold (1963) and Cloete and Steyn (1988b). The removal of phosphate during the lag growth phase as well as during the logarithmic and stationary growth phase when using

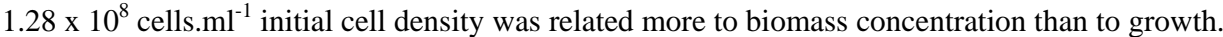

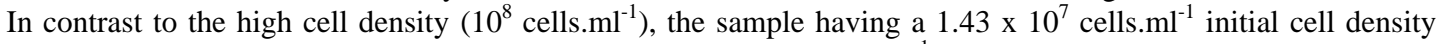
released phosphate into the medium, after an initial rapid uptake $\left(0.4 \mathrm{mgl}^{-1} \mathrm{P}\right)$ during the lag growth phase (Fig. 5). The concentration of phosphate increased to $42.5 \mathrm{mgl}^{-1} \mathrm{P}$ and decreased again to $21 \mathrm{mgl}^{-1} \mathrm{P}$ after $5 \mathrm{~h}$ of growth. Although some phosphate was released from time to time when cells reached the stationary growth phase, complete removal of phosphate occurred during this growth phase.

\section{CONCLUSION}

The results of this investigation show that the removal of phosphate by A. junii was associated with the initial biomass cell concentrations and growth stage. At a high initial cell biomass concentration Acinetobacter junii removed phosphate during the entire duration of the growth study. A low initial cell concentration first released phosphate during active growth and removed phosphate when cells reached the end of the logarithmic growth and/or the stationary growth phase. Concomitant growth of different biomass concentrations and phosphate uptake of $A$. junii in mixed liquor medium showed that the concentration of phosphate uptake was related to biomass concentrations and nutrient gradients which have to be defined and which in full scale plants are separated and governs P-release and uptake.

Acknowledgements - The authors wish to thank the Water Research Commission of South Africa who sponsored this investigation.

\section{REFERENCES}

Arvin E. and Bundgaard E. (1982) Full scale experience with phosphorus removal in an alternating system. In Proc. Post Conf. Seminar on Phosphate Removal in Biological Treatment Processes. Council for Scientific and Industrial Research. Pretoria, South Africa.

Auling G., Pils F., Busse H.J., Karrasch S., Streichan M. and Schon G. (1991) Analysis of the phosphate accumulating microfiora in phosphorus - eliminating, anaerobic-aerobic activated sludge systems by using diaminopropane as a biomarker for rapid estimation of Acinetobacter spp. Appl. environ. Microbiol. 57(12), 3585-3596.

Barnard J. L. (1976) A review of biological phosphorus removal in the activated sludge process. Water SA. 2(3), 136-144.

Bosch M. (1992) Phosphorus uptake kinetics oi Acinetobacter in activated mixed liquor. M.Sc. thesis, University of Pretoria, Pretoria, South Africa.

Brodisch K. E. U. and Joyner S.J. (1983) The role of microorganisms other than Acinetobacter in biological removal in activated sludge process. Wat. Sci. Technol. 15, 117-125.

Buchan L. (1980) The location and nature of accumulated phosphorus in activated sludge. D.Sc. thesis, Univ. of Pretoria, Pretoria, South Africa.

Buchan L. (1981) The location and nature of accumulated phosphorus in seven sludges from activated sludge plants which exhibited enhanced phosphorus removal. Water SA. 7, 1-7.

Buchan L. (1983) Possible biological mechanism of phosphorus removal. Wat. Sci. Technol. 15, 87-103.

Cloete T. E. and Steyn P. L. (1988a) A combined membrane filter immunofluorescent technique for the in situ identification of Acinetobacter in activated sludge. Wat. Res. 22(8), 961-969.

Cloete T. E. and Steyn P. L. (1988b) The role of Acinetobacter as a phosphorus removing agent in activated sludge. Wat. Res. 22 (8), 971-976.

Comeau Y., Hall K. J., Hancock R. E. W and Odhum W. K. (1986) Biochemical model for enhanced biological phosphorus removal. Wat.Res. 20(12), 1511-1521

Deinema M. H. Habets L. H. A., Scholten J. and Webers H. A. A. M. (1980) The accumulation of polyphosphate in Acinetobacter spp. FEMS. Microbiol. Lett. 9, 275-279.

Deinema M. H., van Loosdrecht M. and Scholten A. (1985) Some physiological characteristics of Acinetobacter spp. accumulating large amounts of phosphate. Water Sci. Technol. 17, 119-126.

Fuhs G. W. and Chen M. (1975) Microbiological basis of phosphate removal in the activated sludge process for the treatment of wastewater. Microbiol. Ecol. 2, 119-138.

Gleisberg D. (1992) Phosphate. In Detergents (Edited by de Oude N. T.), pp.179-203. Springer, Berlin. 
Grady C. P. L. and Lim H. C. (1980) Activated sludge. In Biological wastewater treatment theory and applications (Edited by Cheremisinoft P. N.). Marcel Dekker, New York.

Harold F. M. (1963) Accumulation of inorganic polyphosphates in Aerobacter aerogenes, I. Relationship to growth and nucleic acid synthesis. /. Bacteriol. 86, 216-221.

Hiraishi A. K., Masamune K. and Kitamura H. (1989) Characterization of the bacterial population structure in an anaerobicaerobic activated sludge system on the basis of respiratory quinone profiles. Appl. environ. Microbiol. 55(4), 897-901.

Junii E. (1954) Genus III. Acinetobacter Brisou and Prévot. In Bergy' Manual of Systematic Bacteriology (Edited by Krieg N.R. and Holt J.G.), Vol.1, pp. 303-307. Williams \& Wilkins, Baltimore, Md.

Kulaev I. S. and Vagabov V. M. (1983) Polyphosphate metabolism in microbiology. Adv. Microb. Phvsiol. 24, 83-171.

Lawson E. N. and Tonhazy N. E. (1980) Changes in morphology and phosphate uptake patterns of Acinetobacter calcoaceticus strains. Water SA 6(3), 105-112

Lötter L. H. (1985) The role of bacterial phosphate metabolism in enhanced phosphorus removal from the activated sludge process. Wat. Sci. Technol. 17, 127-138.

Lötter L. H. and Murphy M. (1985) The identification of heterotrophic bacterial in an activated sludge plant with particular reference to polyphosphate accumulation. Water SA 11(4), 179-184.

Murphy M. and Lötter L. H. (1986) The effect of acetate on polyphosphate formation and degradation in activated sludge with particular reference to Acinetobacter calcoaceticus: a microscopic study. Water SA 12(2), 63-66.

Nicholls H. A. and Osborn D. W. (1979) Bacterial stress: prerequisite for biological removal of phosphorus. J. Wat. Pollut. Control Fed. 51(3), 557-569.

Pauli A. (1994) The role of Acinetobacter spp. in biological phosphorus removal from forest industry wastewater. Water and Environment Research Institute, p.76. National Board Of Waters and the Environment, Finland Helsinki.

Rosenberg H., Medveczky N. and La Nauze J. M. (1969) Phosphate transport in Bacillus cereus. Biochim. biophys. Ada 193, 159167.

Srinath E. G., Sastry C. A. and Pillai S. C. (1959) Rapid removal of phosphorus from sewage by activated sludge. Experientia 15, 339-340.

Stanier R. Y., Adelberg E. A. and Ingraham G. L. (1976) General Microbiology, 4th edn, pp. 275-280. Macmillan, London. Streichan M., Golecki J. R. and Schon G. (1990) Polyphosphate accumulating bacteria from sewage plants with different processes for biological removal. FEMS Microbial. Ecol. 73, 113-124.

Tam N. F. Y., Wong Y. S. and Lueng G. (1992) Effect of exogeneous carbon sources on removal of inorganic nutrient by the nitrification denitrification process. Wat. Res. 9, 1229-1236.

Toerien D. F.. Gerber A., Lötter L. H. and Cloete T. E. (1990) Enhanced biological phosphorus removal in activated sludge systems. Adv. Microbiol. Ecology. 11, 173-230.

Vaker D., Connell C. H. and Wells W. N. (1967) Phosphate removal through municipality wastewater treatment at San Antonio, Texas. J. Wat. Poll. Cont. Fed. 39, 750.771. 